\title{
Kadar Hematokrit dan Hemoglobin Ikan Sapu-sapu (Pterygoplichthys pardalis) Terpapar Logam Berat Merkuri Klorida
}

\author{
Siti Anikha Idzni ${ }^{1}$, Junardi ${ }^{1}$, Diah Wulandari Rousdy ${ }^{1}$ \\ ${ }^{1}$ Program Studi Biologi, Fakultas MIPA, Universitas Tanjungpura, Jl. Prof. Dr.H. Hadari Nawawi, Pontianak \\ Email: anikhaidzni@gmail.com
}

\begin{abstract}
Mercury chloride $\left(\mathrm{HgCl}_{2}\right)$ is one of the heavy metals that are harmful to the environment and can accumulate in aquatic organisms, such as Sucker Mouth Catfish, Pterygoplichtys pardalis. The purpose of this study was to analyze the damage of the hematocrite values and hemoglobin of $P$. pardalis exposed to mercury chloride. This study used a Randomized Block Design method with 54 male fish and six treatment groups, namely Control (0 ppm); P1 (0.01 ppm); P2 (0.02 ppm); P3 (0.04 ppm); P4 (0.08 ppm); P5 (0.16 ppm). Hematological tests showed a significant difference between treatment and control, while the different hemoglobin values with controls only at a concentration of $0.16 \mathrm{ppm}$. Mercury chloride causes damage to hematological disorders in $P$. pardalis.
\end{abstract}

Keywords: Mercury chloride, hemoglobin, hematocrite, Pterygoplichtys pardalis

\section{PENDAHULUAN}

Merkuri $(\mathrm{Hg})$ merupakan salah satu pencemar perairan yang berbahaya bagi lingkungan dan dapat terakumulasi pada organisme perairan (Nirmala et al., 2012). Aktivitas manusia juga menyebabkan meningkatnya kuantitas merkuri dan telah menjadi sumber masalah bagi kesehatan masyarakat (Clarkson \& Magos, 2006). Kontaminan ini memiliki tingkat toksisitas yang tinggi. Merkuri tidak terdegradasi oleh bakteri sehingga tetap berada secara permanen di lingkungan perairan (Clark, 2001). Merkuri pada umumnya dibagi menjadi dua jenis yaitu merkuri organik dan merkuri anorganik. Salah satu contoh dari merkuri anorganik adalah merkuri klorida $\left(\mathrm{HgCl}_{2}\right)$. Senyawa ini bersifat toksik bagi makhluk hidup terutama manusia dalam dosis tertentu dan kurun waktu yang lama (Hidayat, 2011).

Merkuri masuk ke dalam jaringan tubuh melalui beberapa jalan, yaitu saluran pernapasan, pencernaan (makanan) dan penetrasi melalui kulit. Merkuri yang masuk ke dalam tubuh organisme air tidak dapat dicerna, akan tetapi merkuri mampu bergabung dengan lemak dan masuk kedalam membran sel. Merkuri yang bergabung dengan lemak pada akhirnya akan menumpuk (terakumulasi) di dalam organ, terutama organ respirasi (insang), organ detoksikasi (hati) dan organ ekskresi (ginjal) (Palar, 2004).

Ikan Sapu-sapu (Pterygoplichthys pardalis) merupakan salah satu spesies ikan yang dapat terkontaminasi oleh merkuri. Hal ini disebabkan karena ikan ini hidup bebas di lingkungan perairan seperti sungai, danau, dan rawa. Selain itu, ikan sapu-sapu merupakan hewan pemakan alga atau sisa-sisa pakan sehingga selama ini sebagian besar masyarakat memanfaatkan ikan tersebut sebagai pembersih akuarium dan di beberapa daerah digunakan sebagai bahan pangan (Pinem et al., 2016).

Proses akumulasi logam pada ikan diawali dengan proses pengambilan (uptake) melalui insang dan kemudian diserap ke dalam seluruh jaringan tubuh yang kemudian tersimpan di dalamnya. Faktor yang mempengaruhi proses uptake merkuri dan jumlah akumulasinya antara lain kecepatan metabolisme, ukuran, jenis, alkalinitas, $\mathrm{pH}$, suhu, tingkat kontaminasi, sumber, serta tingkat kehidupan organisme itu sendiri. Menurut Heath (1987), masuknya merkuri ke dalam jaringan tubuh ikan terjadi ketika merkuri diangkut oleh darah dan berikatan dengan protein hemoglobin dalam sel darah merah ikan.

Pengaruh merkuri terhadap darah dapat menghambat sintesis heme dan memperpendek usia sel eritrosit. Hal tersebut terjadi karena aktivitas berbagai enzim yang diperlukan untuk sintesis heme dihambat. Merkuri terendap dalam sel eritrosit dan menyebabkan kerusakan pada sel eritrosit. Kerusakan sel eritrosit yang mengandung merkuri ditandai pecahnya sel darah merah sebelum sel darah merah matang, sehingga terjadi penurunan jumlah sel darah merah (Ramona, 2008). 
Penelitian mengenai pengaruh paparan $\mathrm{HgCl}_{2}$ pada ikan sapu-sapu belum pernah dilakukan. Berdasarkan hal tersebut, maka perlu dilakukan penelitian untuk mengetahui dan menganalisis nilai hematokrit serta hemoglobin pada ikan sapu-sapu (Pterygoplichtys pardalis) yang dipaparkan logam berat merkuri klorida $\left(\mathrm{HgCl}_{2}\right)$.

\section{BAHAN DAN METODE}

\section{Waktu dan Tempat Penelitian}

Penelitian dilakukan selama tiga bulan yaitu mulai bulan Februari hingga April 2017. Penelitian dilakukan di Laboratorium Bologi dan Zoologi Fakultas Matematika dan Ilmu Pengetahuan Alam Universitas Tanjungpura Pontianak.

\section{Alat dan Bahan}

Alat-alat yang digunakan dalam penelitian ini adalah akuarium yang berukuran $35 \mathrm{~cm}$ x $24,5 \mathrm{~cm}$ x $19,5 \mathrm{~cm}$ sebanyak 6 buah, alat gelas, bak bedah, haemometer, jarum suntik, $\mathrm{pH}$ meter Hanna, sentrifuse SH120-II, tabung eppendorf dan timbangan analitik.

Bahan-bahan yang digunakan pada penelitian ini antara lain akuades, ikan sapu-sapu (Pterygoplichthys pardalis), EDTA, $\mathrm{HCl} 0,1 \mathrm{~N}$ dan merkuri klorida $\left(\mathrm{HgCl}_{2}\right)$.

\section{Prosedur Kerja}

Persiapan Wadah dan Ikan Uji

Akuarium disterilkan menggunakan kalium permanganat dengan dosis $25 \mathrm{ppm}$ dan dibilas menggunakan air bersih. Akuarium kemudian diisi dengan air sebanyak \pm 6 liter. Setiap akuarium di isi sebanyak 3 ekor ikan uji dengan bobot badan 30$32 \mathrm{~g}$, berusia 4 bulan, berkelamin jantan, dan panjang tubuh $12-13 \mathrm{~cm}$. Masa pemeliharaan diawali dengan mengaklimasikan ikan terhadap lingkungan yang baru selama 2 minggu. Kemudian ikan diberi perlakuan dengan beberapa macam konsetrasi $\mathrm{HgCl}_{2}$ selama 20 hari.

\section{Uji Pendahuluan}

Ikan yang digunakan dalam uji pendahuluan sebanyak 15 ekor dibagi masing-masing 3 ekor dalam 5 perlakuan. Uji pendahuluan ini bertujuan untuk mengetahui kisaran konsentrasi yang digunakan pada uji sebenarnya dan lama pemaparan selama 20 hari. Kisaran konsentrasi yang digunakan pada uji pendahuluan mengacu pada standar baku mutu air terhadap logam berat untuk merkuri sebesar 0,001 ppm (EPA, 1973). Hewan diperlakukan dengan 5 macam konsentrasi yaitu; kontrol (0 ppm), P1 (1 ppm), P2 (0,1 ppm), P3 (0,01 ppm), P4 (0,001 ppm). Pada uji sebenarnya rentang konsentrasi yang dipilih dari hasil uji pendahuluan adalah $0,01 \mathrm{ppm}$.

\section{Pengambilan Sampel Darah}

Alat suntik dan tabung eppendorf dibilas dengan antikoagulan EDTA. Darah ikan sapu-sapu diambil dengan menggunakan syringe yang ditusukkan pada bagian sisi ventral tubuh. Darah yang telah diambil kemudian dimasukkan ke dalam tabung eppendorf.

\section{Pengukuran Hemoglobin}

Pengukuran kadar hemoglobin dilakukan dengan metode Sahli. Prinsip metode ini adalah mengkonversikan hemoglobin dalam darah ke dalam bentuk asam hematin oleh asam klorida. Darah dihisap menggunakan pipet Sahli sampai skala $20 \mathrm{~mm} 3$, ujung pipet yang telah digunakan dibersihkan dengan kertas tissue. Darah kemudian dipindahkan ke dalam tabung hemoglobin yang berisi $\mathrm{HCl} 0,1 \mathrm{~N}$ lalu didiamkan 3-5 menit agar hemoglobin bereaksi dengan $\mathrm{HCl}$ membentuk asam hematin. Darah kemudian diaduk dan ditambahkan akuades tetes demi tetes hingga warnanya sama dengan warna standar. Pembacaan skala dilakukan dengan melihat tinggi permukaan larutan yang dicocokkan dengan haemometer yang berarti banyaknya hemoglobin dalam gram per 100 $\mathrm{ml}$ darah (Sunarto et al., 2015).

\section{Pengukuran Hematokrit}

Darah dihisap menggunakan tabung mikrohematokrit berlapis heparin dengan sistem kapiler. Darah setelah mencapai $3 / 4$ bagian tabung, kemudian salah satu ujung tabung disumbat dengan plastisin. Tabung kapiler yang telah berisi darah kemudian diputar dengan menggunakan sentrifuse pada $3000 \mathrm{rpm}$ selama 5 menit. Pengukuran dilakukan dengan membandingkan volume unsur seluler darah terhadap volume total bagian darah menggunakan skala hematokrit.

\section{Analisis Data}

Nilai kadar hematokrit dan kadar hemoglobin antar perlakuan dianalisis dengan analisis varian (ANAVA) satu arah. Hasil ANAVA antar perlakuan yang signifikan dianalisis lebih lanjut menggunakan analisis Tukey pada selang kepercayaan 95\%. Gambaran histologis insang dianalisis secara deskriptif

\section{HASIL DAN PEMBAHASAN \\ Hasil}

\section{Nilai Hematokrit dan Hemoglobin}

Hasil rerata tingkat penurunan nilai hematokrit menunjukkan kelompok P3, P4, dan P5 berbeda nyata dengan kontrol $(p<0,05)$ sedangkan nilai 
hemoglobin menunjukkan kelompok P5 berbeda nyata dengan kontrol $(p<0,05)$, tetapi tidak berbeda nyata dengan semua kelompok perlakuan (Tabel 1.)

Tabel 1. Nilai Perubahan Hematokrit dan Hemoglobin Rata-rata \pm SD Ikan Sapu-sapu (Pterygoplichthys pardalis) pada setiap perlakuan.

\begin{tabular}{crr}
\hline $\begin{array}{c}\text { Kelompok } \\
\text { Perlakuan }\end{array}$ & HCT $(\%)$ & $\begin{array}{c}\text { Hemoglobin } \\
(\mathbf{g} / \mathbf{d L})\end{array}$ \\
\hline K & $36,91 \pm 12,98^{\mathrm{a}}$ & $7,00 \pm 1,00^{\mathrm{a}}$ \\
P1 & $28,67 \pm 10,46^{\mathrm{ab}}$ & $5,67 \pm 1,15^{\mathrm{ab}}$ \\
P2 & $21,93 \pm 6,02^{\mathrm{ab}}$ & $5,87 \pm 0,23^{\mathrm{ab}}$ \\
P3 & $19,23 \pm 6,19^{\mathrm{b}}$ & $5,23 \pm 0,40^{\mathrm{ab}}$ \\
P4 & $17,12 \pm 6,27^{\mathrm{b}}$ & $4,87 \pm 0,23^{\mathrm{ab}}$ \\
P5 & $13,00 \pm 6,06^{\mathrm{b}}$ & $4,40 \pm 1,04^{\mathrm{b}}$ \\
\hline
\end{tabular}

Keterangan: Nilai yang diikuti oleh huruf superscript yang berbeda pada kolom yang sama menunjukkan hasil berbeda nyata pada taraf $\alpha=0,05$.

\section{Pembahasan}

\section{Nilai Hematokrit dan Hemoglobin}

Hasil penelitian menunjukan rata-rata nilai hematokrit ikan sapu-sapu pada konsentrasi $\mathrm{HgCl}_{2}$ $0,04 \mathrm{ppm}$ sebesar $19,23 \%, \mathrm{HgCl}_{2} 0,08 \mathrm{ppm}$ sebesar $17,12 \%$, dan $\mathrm{HgCl}_{2}$ 0,16 ppm sebesar 13,00\%. Hasil nilai hematokrit tersebut berbeda nyata dengan kontrol sebesar $36,91 \%$. Hasil penelitian ini sesuai dengan pernyataan Nabib dan Pasaribu (1989), apabila nilai hematokrit di bawah $30 \%$ menunjukkan adanya defisiensi eritrosit. Jumlah sel darah merah, hematokrit, dan hemoglobin semakin menurun seiring dengan bertambahnya konsentrasi merkuri di dalam media pemeliharaan (Yuniar, 2009).

Senyawa $\mathrm{HgCl}_{2}$ masuk ke dalam tubuh bersamaan dengan oksigen yang kemudian akan diikat oleh sel darah dan didistribusikan ke organ tubuh lainnya seperti daging dan tulang, ada pula yang masuk ke dalam hati untuk kemudian diekskresikan. Menurut Murtini dan Novalia (2007), logam pada tubuh hewan akan diabsorpsi darah dan berikatan dengan protein darah yaitu albumin dan globulin, kemudian didistribusikan ke seluruh jaringan tubuh. Proses akumulasi logam dalam jaringan ikan terjadi setelah absorpsi logam dari air atau melalui pakan yang terkontaminasi.

Perubahan nilai hematokrit dapat menggambarkan adanya tekanan fisiologis terhadap ikan atau kemampuan oksigen yang dapat diangkut oleh darah. Hal ini disebabkan karena ikan mengalami hipoksia akibat terpapar merkuri. Hipoksia adalah kondisi kurangnya pasokan oksigen di sel dan jaringan tubuh untuk menjalankan fungsi normalnya. Hipoksia pada ikan disebabkan oleh hiperplasia dalam lamella sekunder (Ishikawa et al., 2007) dan kondisi degenerasi insang yang lebih parah seperti fusi lamella dan reduksi lamella.

Nilai hemoglobin selama penelitian mengalami penurunan antar ikan uji. Nilai hemoglobin berbeda nyata dengan kontrol hanya pada konsentrasi $0,16 \mathrm{ppm}$ sementara tidak berbeda nyata pada konsentrasi perlakuan. Kadar hemoglobin selaras dengan jumlah eritrosit, semakin rendah kadar hemoglobin semakin rendah pula jumlah eritrosit (Heath, 1987). Kadar hemoglobin berhubungan erat dengan kondisi histopatologi insang. Kerusakan insang seperti edema, hiperplasia dan fusi lamella sekunder menyebabkan berkurangnya efisiensi insang dalam menyerap oksigen dalam perairan. Penyerapan oksigen yang rendah oleh insang akan membuat proses metabolisme ikan terganggu. Menurut Vinodhini (2009), rendahnya kadar hemoglobin ikan dapat disebabkan oleh beberapa faktor, salah satunya adalah pencemaran $\mathrm{Hg}$.

Merkuri memengaruhi fungsi enzim coproporfirinogen oksidase dalam sintesis hemoglobin (Palar, 1994). Merkuri dapat meningkatkan aktivitas enzim coproporfirinogen oksidase dan menurunkan aktivitas ferochetalase yang mengkatalis besi (Fe) ke dalam protoporphyrin (Klaassen, 2001). Protoporphyrin merupakan senyawa organik untuk pembentukan heme yang akan berikatan dengan Fe dan memiliki kemampuan untuk mengikat O2 (Burden et al., 1998). Penghambatan aktivitas enzim tersebut akan menurunkan produksi hemoglobin.

Merkuri akan meningkatkan kadar Asam Amino Levulinat (ALA) yang diperlukan dalam proses sintesis heme untuk membentuk porphobilinogen sebagai prekursor hemoglobin (Bhavagan, 1992). Peningkatan kadar ALA akan mempengaruhi pembentukan porphobilinogen serta protoporphyrin-9. Protoporphyrin-9 yang terakumulasi dalam sel darah merah dapat menyebabkan penurunan jumlah sel darah merah dan pengurangan usia sel darah merah. Seiring dengan proses tersebut maka sintesis $\mathrm{Hb}$ akan terhambat (Palar, 1994).

Jumlah sel darah merah pada ikan semakin berkurang seiring dengan semakin tingginya kandungan logam berat dalam darah. Hal ini menunjukkan bahwa jumlah sel darah merah matang semakin berkurang seiring dengan peningkatan konsentrasi logam berat dalam darah sehingga sel darah merah yang beredar merupakan sel darah merah yang masih muda yang ukurannya 
lebih besar daripada sel darah merah yang sudah matang (Musthapia dan Sunarno, 2006).

Menurut Albahary (1972), tingginya kandungan logam berat dalam sel darah merah sangat tinggi diketahui karena lebih dari 90\% logam berat yang terkandung dalam darah telah berikatan dengan sel darah merah sehingga sel darah merah menjadi mudah pecah, selain itu terjadi pula penghambatan proses eritropoiesis dalam sumsum tulang. Kondisi seperti ini mengakibatkan umur sel darah merah menjadi pendek, menurunnya jumlah sel darah merah dan retikulosit sehingga jumlah sel darah merah semakin rendah.

Penurunan persentase hemoglobin pada ikan uji dapat disebabkan karena paparan merkuri sebagai radikal bebas yang merusak membran sel darah merah dan penurunan nilai hematokrit (Sapna et al., 2011).

\section{DAFTAR PUSTAKA}

Albahary C, 1972, 'Lead and Hemopoesis', Amsterdam Journal Medical, vol. 52, hal. 367-377.

Bhavagan NV, 1992, Medical Biochemistry, Jones and Bartlett, Boston, $980 \mathrm{p}$.

Burden VM, Sandheunrich MB, dan Caldwell CA, 1998, 'Effect of Lead on the Growth and $\delta$ Aminolevulinic acid Dehydratase Activity of juvenile Rainbow Trout', Oncorhynchus mykiss, Environmental Pollution, vol. 101, hal. 285-289.

Clark R, 2001, Marine pollution, Oxford University Press, New York, $231 \mathrm{p}$.

Clarkson TW and Magos L, 2006, 'The Toxicology of Mercury and its Chemical Compounds', Critical Reviews in Toxicology, vol. 36, no. 8, 609-662.

Environmental Protection Agency, 1973, Water Quality Criteria, EPA, Ecology Research Series, Washington.

Heath AG, 1987, Water Pollution and Fish Physiology, CRC Press, Inc. Florida, 145 p.

Hidayat D, 2011, 'Pengaruh Sianida pada Fotoreduksi $\mathrm{Hg}$ (II) yang dikatalis $\mathrm{Ti}_{2}$ '. Jurnal Molekul, vol. 6 , no, 1 , hal. $40-45$

Ishikawa N, Maria M, Julio VL, dan Caludia MF, 2007, 'Hematological Parameters in Nile tilapia, Oreochromis niloticus, Eksposed to SubLethal Consentration of Mercury', Brazillian Archives of Biology and Technology, vol. 5, no. 4, hal. 619-626.

Klaassen CD, 2001, Toxicology the Basic Science of Poisons, Sixth Edition, Medical Publishing Division, New York, hal. 827-834.
Murtini, JT \& Novalia, R, 2007, 'Kandungan Logam Berat Pada Ikan, Air dan Sedimen di Waduk Saguling Jawa Barat', Jurnal Pasca Panen dan Bioteknologi Kelautan dan Perikanan, vol. 2, no. 2, hal. 153-159.

Musthapia I dan Sunarno MTD, 2006, Dampak Polutan Timbal Pada Ikan dan Manusia, Makalah Seminar Nasional Limnologi 2006, LIPI, Jakarta.

Nabib R, dan Pasaribu FH, 1989, Patologi dan Penyakit Ikan, Pusat Antar Universitas Bioteknologi, Institut Pertanian Bogor, Bogor, hal. 158.

Nirmala K, Yuniar V, Hastuti WP, 2012, 'Toksisitas Merkuri (Hg) Terhadap Tingkat Kelangsungan Hidup, Pertumbuhan, Gambaran Darah dan Kerusakan Organ Pada Ikan Nila (Oreochromis niloticus)', Jurnal Akuakultur Indonesia, vol. 11, no. 1. hal. 38-48.

Palar H, 1994, Pencemaran dan Toksikologi Logam Berat, Jakarta, Rineka Cipta, hal. 152.

Palar H, 2004, Pencemaran dan Toksikologi Logam Berat, Jakarta, Rineka Cipta, hal. 152.

Pinem FM, Pulungan CP, dan Efizon D, 2016, 'Reproductive Biology of Pterygoplichthys pardalis in the Air Hitam River Payung Sekaki District, Riau Province', Jurnal Online Mahasiswa, vol. 3, no. 1, hal. 1-14.

Ramona BL, 2008, Handbook of Pathophysiology fourth edition, MPS Limited, A Macmillan Company, Philadelphia, $431 \mathrm{p}$.

Sapna R, Kusum S, Farhan A, Vinita A, 2011, 'Ameliorative Effect of Tocopherol Against Mercuric Chloride-Induced Changes on Haematology of Albino Rats', IJPI'S Journal of Pharmacology and Toxicology, vol 1, no. 2, hal. 120-127.

Sunarto, Hasan H, dan Yanto H, 2015, 'Studi Hematologi Untuk Diagnosa Penyakit Ikan Secara Dini di Sentra Produksi Budidaya Ikan Air Tawar Sungai Kapuas Kota Pontianak', Jurnal Akuatika, vol. 6, no. 1, hal. 11-20.

Vinodhini R, and Narayanan M, 2009, 'The Impact of Toxic Heavy Metal on Hematological Parameters in Common Carp (Cyprinus carpio L.), Iran', Journal Environment Health Science English, vol. 6, no.1, hal. 23-28.

Yuniar V, 2009, Toksisitas Merkuri (Hg) terhadap Tingkat Kelangsungan Hidup, Pertumbuhan, Gambaran Darah dan Kerusakan Organ pada Oreochromis niloticus, Skripsi, Institut Pertanian Bogor, Bogor. 